\title{
On the Contemporary Patriotism Education of Russia
}

\author{
Lie-Ming FANG ${ }^{1, a,}$ Wei-Ran ZHANG ${ }^{2, b, *}$ \\ ${ }^{1}$ Shandong Youth University of Political Science, Jinan, China \\ ${ }^{2}$ Beijing Institute of Petrochemical Technology, Beijing, China \\ afanglieming@126.com, bzhangweiran@bipt.edu.cn \\ *corresponding author
}

Keywords: Russia; Patriotism; Education

\begin{abstract}
Patriotism education refers to the ideological education that nourishes the love for one's own country and devotion to her, which can inspire citizen's patriotic enthusiasm, strengthen the cohesion and cultivate the national spirit. Russia carries on patriotism education mainly in the following ways: enact regulations to facilitate the implementation of the patriotism education; take youth as the key patriotism education target; launch patriotism education activities at all levels of education department; conduct patriotism education activities through new media; carry out various activities of patriotism education; name cities, streets, subways stations, universities after historical celebrities, patriotic heroes, which unconsciously exerts patriotic influence on people; bring the influence of Eastern Orthodox on patriotism education into full play. The strategies for strengthening contemporary patriotism education adopted by Russia provide enlightenments and references to other countries in the world.
\end{abstract}

\section{Introduction}

Patriotism means love and loyal support of one's own country, which is a positive and supportive attitude to "motherland" by individuals or collectives. Patriotism education refers to the ideological education that nourishes the love for the motherland and devotion to her. Carrying out patriotic education activities can inspire the national patriotic enthusiasm, enhance national cohesion and cultivate the national spirit. The deep reasons underlying the collapse of the Soviet Union are the impact of values in western countries on the national culture of Soviet Union, leading to the spreading of liberalism and democracy and lack of faith. In order to solve the domestic social problems in Russia arose ten years after the collapse of the Soviet Union, Russian President Vladimir Putin put forward the "New Russian Idea" in the article "Russia at the Turn of the Century", on December 30, 1999 which contains four parts: "patriotism", "consciousness of building a strong country", "national idea" and "social cohesion", hoping to successfully guide the social value construction of Russia in the new period. "New Russian Idea" has been well received by the Russian people. Russia strengthens the national patriotism education by adopting various strategies.

\section{Enact Regulations to facilitate the implementation of the patriotism education}

Russia attaches great importance to the education of patriotism and it is the one of the earliest countries to put patriotic education into national education regulations. After Putin came to power, Russia carried out citizens' patriotism education nationwide. It actively explores the ways to the cultivate citizen's patriotism, eternal values, awareness of hardship and crises and devotion to the 
motherland. Russia has developed a number of guidelines for patriotism education of citizens, including a complete set of laws and regulations, morality and ethics system, organizing forms, research method, information processing ways, and funding modes. It is implemented by 12 departments including the Ministry of Defense, Ministry of Culture, the Ministry of Education and so on to ensure the effectiveness of patriotic education in the whole range of Russia and inter region. The state has invested a lot of money on the patriotism education, and the fund is increased year by year. On February 6, 2001, Russia issued "The National Outline for the Patriotic Education of Russian Citizens (2001-2005)"; On July, 11, 2005, Russia issued "The National Outline for the Patriotic Education of Russian Citizens (2006-2010)"; On October 5, 2010, Russia issued "The National Outline for the Patriotic Education of Russian Citizens (2011-2015)"; On February 16, 2015, Russia issued "The National Outline for the Patriotic Education of Russian Citizens (2016-2020)". The Russian citizen patriotism education investment budget from the year 2001 to the year 2020 is listed in the following table.

Russian citizen patriotism education investment budget (2001- 2020) [1]

\begin{tabular}{|l|c|c|c|c|}
\hline Year & $2001-2005$ & $2006-2010$ & $2011-2015$ & $2016-2020$ \\
\hline $\begin{array}{l}\text { National budget } \\
\text { (Million rubles) }\end{array}$ & 177,95 & 497,8 & 777,2 & $1,886,5$ \\
\hline
\end{tabular}

\section{Take youth as the key target of patriotism education}

Since youth are the future and hope of a nation, they are taken as the key target of the patriotism education in Russia. On June 18, 1997, Russia government issued the federal program "Russian Youth (1998-2000)"; On December 27, 2000, the federal program "Russian Youth (2001-2005)" was issued. Then "Russian Youth (2006-2010)" was issued. Being one of the aims of the "federal program", the patriotism education to the youth is put on the primary position and the funding in the budget is keeping increased. In the "Russian Youth (1998-2000)" a total budget of about 2,476 million rubles was made on youth patriotism education, among which budget in 1998 being 700 million rubles, the budget in 1999 being 822,5 million rubles, and the budget in 2000 is 953,5 million rubles [2] ; In the "Russian Youth (2001-2005)" investment budget for youth patriotism education in 2001 is 7,910 million rubles, in 2002 the budget is 813 million rubles and in 2003 the budget is 831,1 million rubles [3] (note: in 1998 ruble denomination is reduced by 1000 times, that is, 10,000 rubles before 1998 is now the equivalent of 10 rubles). On February 7, 2011, "Russian Youth (2011-2015)" was issued. In the article 4 of Federal plan for youth work, strengthening youth patriotism education and strengthening the construction of national culture are mentioned, as is shown in the plan, " "I $\mathrm{m}$ a Russian' should be deep rooted in Russian youth's hearts. Take precautions against the ethnic and religious political extremism" [4]. The National youth patriotism education investment budget has been increased year by year. Patriotism education arouses the traditional ideas like great nation consciousness and sense of national pride in the minds of the Russian, strengthens national unity, and constantly improves the patriotic enthusiasm of youth organizations, and strengthens the nation's leading and guidance of youth organizations.

\section{Carry out patriotism education activities at all levels of education departments}

Patriotism education activities are carried out at all levels of Russian education departments. Courses like history, geography, economy, politics, law and other courses are set up and there is penetration 
of patriotism education in different subjects, exerting influence on students directly or indirectly. Take Moscow Friendship University for example. It set up a series of tutorials named "Knowledge about Motherland", which includes four parts, namely, Russian history, Russian language, History of Russian philosophy and History of Russian literary. The local governments also work actively with the central Government and encourage the teachers to take class on patriotic education. And by granting or increasing the amount of scholarships, it helps to develop students' sense of patriotism. The education of patriotism helps young people gain a better understanding of their own history and culture, a clear recognition of their own position and responsibility in the society and a stronger sense of national pride.

\section{Launch national patriotism activities through the media}

The Russian government broadcast films and music on the theme of patriotism on TV, and hold television debates, broadcast patriotic video and music through the network, guiding people to strengthen their determination and faith in loving the motherland and the construction of the country from the height of the combination of history and reality. Since February 2005, the Russian government broadcasts 18 hours a day in the military and patriotic education programs through specialized military channel TV.

\section{Conduct patriotism education through a variety of activities}

The Russian federal and local government organized hundreds of activities each year to remind people to remember history and cherish the traditional culture. Hold the art and photography exhibition on the Great Patriotic War: "Russian National Heroic Undertaking in the Eyes of Witnesses and Modern Artists", which reveals to the audience their obligations, educates them to respect their country's history, military glory and the heroic undertaking; Hold a good patriotic art and Documentary Film Festival whose aim is to let people know that the best way to understand the world is to understand the motherland. Film Festival shows responsibility, honor, spirit and love of country, respect for the individual through works of art. Another important way is to conduct the extracurricular activities through education institutions at all levels, such as the military training, the historical knowledge contest, large school games, visiting museums and memorial and other measures to strengthen the education of patriotism. In Russia, many of the Great Patriotic War Memorial museums have regular free open day, for the students and new soldiers to visit.

\section{Instill patriotism education through environment}

Many cities, streets and higher education institutions are named after historical celebrities, patriotic heroes to exert a subtle influence on the national patriotism education. For example, the city name such as "Gagarin", street names such as Pushkin street, subway station names such as "October" (in memory of the October Revolution), university names such as D. Mendeleev University of Chemical Technology of Russia.

\section{Bring the influence of Eastern Orthodox on patriotism education into full play}

Russian prime minister Dmitry Medvedev pointed out that "social morality is rooted in the Russian people's religious tradition and in its humanitarian tendency. For centuries, religious ascetics prove 
ideals such as mutual respect, love and passion, patriotism, stable family and honest labor through their own actions." The Russian state duma lawmakers also suggested making use of the power of the Eastern Orthodox church in the education. All of the Russian moral and life value are from history, from the Eastern Orthodox church. The church can help the Russians to protect their motherland and help the young people back to the historical roots, which is the foundation on which the country will grow stronger. With more than one thousand years of history, Eastern Orthodox church is the largest religious groups in the Russian federation. It has been fully integrated into the religious culture atmosphere and has become the carrier to strengthen patriotic appeal and help the unity of the faith. The Russian government should give full play to the advantages of the orthodox in carrying out national patriotism education.

\section{Conclusions}

All the countries in the world attach importance to national patriotism education which is a power summons the strongest enthusiasm. Patriotism education inspires the patriotic enthusiasm, enhances national cohesion and cultivates the national spirit. The strategies for strengthening contemporary patriotism education adopted by Russia provide enlightenments and references to other countries in the world.

\section{Acknowledgement}

The paper is sponsored by three projects: Shandong Social Science Planning Fund Program-Youth Research (funded by Youth Research Center of Shandong Province) (NO. 14CQSJ04); Outstanding Young Teachers Training Project of Shandong Youth University of Political Science; Doctoral Research Fund Project of Shandong Youth University of Political Science.

\section{References}

[1] The National Outline for the Patriotic Education of Russian Citizens (2001-2005),

The National Outline for the Patriotic Education of Russian Citizens (2006-2010),

The National Outline for the Patriotic Education of Russian Citizens (2011-2015),

The National Outline for the Patriotic Education of Russian Citizens (2016-2020).

[2] The Federal Program "Russian Youth (1998-2000)".

[3] The Federal Program "Russian Youth (2001-2005)".

[4] The Federal Program "Russian Youth (2011-2015)".

[5] Fang LieMing, On the Strategies Adopted by the Youth Organization "Nash" (Nashi) in Promoting Youth Cohesion, Youth Research China, (2013) No. 6. (in Chinese).

[6] Fang LieMing, Youth Organizations and National Security of Russia, Youth Research, (2014) No. 6. (in Chinese).

[7] Fang LieMing, On the Socialized Management of Russian Youth Organization and its Enlightenment, Journal of Youth, (2014) No. 8. (in Chinese). 